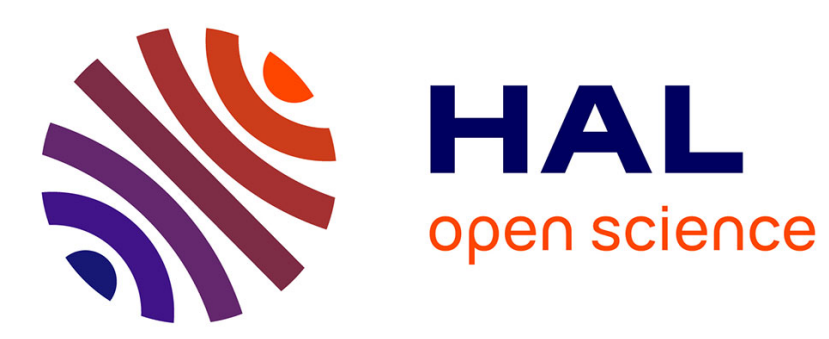

\title{
Atom Probe Studies of Supercooled Liquids
}

\author{
H. Read, K. Hono, A. Tsai, A. Inoue
}

\section{To cite this version:}

H. Read, K. Hono, A. Tsai, A. Inoue. Atom Probe Studies of Supercooled Liquids. Journal de Physique IV Proceedings, 1996, 06 (C5), pp.C5-211-C5-216. 10.1051/jp4:1996534 . jpa-00254413

\section{HAL Id: jpa-00254413 https://hal.science/jpa-00254413}

Submitted on 1 Jan 1996

HAL is a multi-disciplinary open access archive for the deposit and dissemination of scientific research documents, whether they are published or not. The documents may come from teaching and research institutions in France or abroad, or from public or private research centers.
L'archive ouverte pluridisciplinaire HAL, est destinée au dépôt et à la diffusion de documents scientifiques de niveau recherche, publiés ou non, émanant des établissements d'enseignement et de recherche français ou étrangers, des laboratoires publics ou privés. 


\title{
Atom Probe Studies of Supercooled Liquids
}

\author{
H.G. Read, K. Hono, A.P. Tsai and A. Inoue* \\ Third Research Group, National Research Institute for Metals, 1-2-1 Sengen, Tsukuba, Ibaraki 305, Japan \\ * Institute for Materials Research, Tohoku University, Sendai 980-77, Japan
}

\begin{abstract}
Phase transformations in the supercooled liquid region (between $T_{8}$ and $T_{\text {cryst }}$ ), prior to the onset of crystallization, in amorphous Pd-Ni-P alloys remain controversial. It has been previously proposed that the amorphous alloy decomposes into two amorphous phases prior to the crystallization reaction when annealed in the supercooled liquid region. Investigations by DSC, Mössbauer spectroscopy, X-ray diffraction (XRD), transmission electron microscopy (TEM) small-angle X-ray scattering (SAXS) and atom probe field ion microscopy (APFIM) have since corroborated or refuted phase separation prior to crystallization in the supercooled liquid region of $\mathrm{Pd}$ Ni-P alloys.

The microstructural development during annealing in the supercooled liquid region of amorphous $\mathrm{Pd}_{46} \mathrm{Ni}_{36} \mathrm{P}_{18}$, which is supposedly of phase-separating composition, is compared and contrasted with those of $\mathrm{Pd}_{48} \mathrm{Ni}_{32} \mathrm{P}_{20}$ and $\mathrm{Pd}_{40} \mathrm{Ni}_{10} \mathrm{Cu}_{30} \mathrm{P}_{20}$. TEM showed that the as-quenched alloys were fully amorphous and APFIM analysis showed random solute distributions, typical of amorphous materials. Annealing in their respective supercooled liquid regions did not result in the formation of compositionally modulated microstructures prior to the onset of crystallization.
\end{abstract}

\section{INTRODUCTION}

Amorphous alloys are metastable and crystallise when heated near or above their crystallization temperature $T_{X}$. Pd-Ni-P amorphous alloys have glass transition temperatures $T_{g}$ below $T_{c n \text { st }}$ and the supercooled liquid region (between $T_{g}$ and $T_{X}$ ) is relatively wide compared with other amorphous alloys. Amorphous alloys having wide supercooled liquid regions may be prepared as bulk alloys and thus have attracted increasing attention for commercial applications. Phase transformations in the supercooled liquid region, prior to the onset of crystallization, in amorphous Pd-Ni-P alloys remain controversial. It was proposed, based on differential scanning calorimetry (DSC) results [1], that the amorphous alloy decomposes into two amorphous phases prior to the crystallization reaction when annealed in the supercooled liquid region, thus supposedly giving rise to the double $T_{g}$ observed in DSC. Phase separation was reported in only Pd-Ni-P alloys having P contents between 16 and 19 at.\% [2]. The exothermic reaction in the DSC traces was sharper than that associated with structural relaxation and X-ray analysis did not reveal the formation of a crystalline phase. Phase separation of the amorphous phase necessitates a metastable miscibility gap within the metastable amorphous region. It was further suggested that the stability of the amorphous phase was determined not by its inherent stability per se but rather by the instability of the crystalline phases formed upon devitrification [1,3]. Subsequent investigations by DSC of $\mathrm{Pd}_{40} \mathrm{Ni}_{40} \mathrm{P}_{20}$ and $\mathrm{Pd}_{41} \mathrm{Ni}_{41} \mathrm{P}_{18}$ [4, 5], Mössbauer spectroscopy of $\mathrm{Pd}_{40} \mathrm{Ni}_{40} \mathrm{P}_{20}$ [4], X-ray diffraction (XRD) of $\mathrm{Pd}_{41} \mathrm{Ni}_{41} \mathrm{P}_{18}$ [5], transmission electron microscopy (TEM) of $\mathrm{Pd}_{41} \mathrm{Ni}_{41} \mathrm{P}_{18}$ [5] and atom probe field ion microscopy (APFIM) of $\mathrm{Pd}_{35} \mathrm{Ni}_{45} \mathrm{P}_{20}$ [6] have since suggested phase separation prior to crystallization in the supercooled liquid region of Pd-Ni-P alloys. Phase separation supposedly results in the formation of domains enriched in $\mathrm{Pd}$ and depleted in $\mathrm{P}$ and vice versa, within $60 \mathrm{~s}$ upon annealing between 605 and $630 \mathrm{~K}$ [5], prior to the formation of a nanocrystalline NiPd face centred cubic (FCC) solid solution [7]. Prolonged annealing results in the nucleation and growth of larger grains of complex crystallization products $[7,8]$.

However, some previous investigations have also refuted the hypothesis of phase separation. From the results of TEM analysis of $\mathrm{Pd}_{41} \mathrm{Ni}_{41} \mathrm{P}_{18}$ [8], it was suggested that the exotherm observed in DSC was 
due to the precipitation of the nanocrystalline NiPd FCC solid solution. Small-angle X-ray scattering (SAXS) of $\mathrm{Pd}_{46} \mathrm{Ni}_{36} \mathrm{P}_{18}$ did not reveal any evidence of phase separation prior to crystallization during annealing in the supercooled liquid region [9]. APFIM analysis of $\mathrm{Pd}_{21} \mathrm{Ni}_{45} \mathrm{P}_{17}$ and $\mathrm{Pd}_{50} \mathrm{Ni}_{30} \mathrm{P}_{20}$ did not reveal phase separation during annealing in the supercooled liquid region [10].

In this research, the microstructural development during annealing in the supercooled liquid region (as followed by APFIM, TEM, HREM and DSC) of amorphous $\mathrm{Pd}_{46} \mathrm{Ni}_{36} \mathrm{P}_{18}$, which is supposedly of phase-separating composition, is compared and contrasted with those of $\mathrm{Pd}_{48} \mathrm{Ni}_{32} \mathrm{P}_{20}$ and $\mathrm{Pd}_{40} \mathrm{Ni}_{10} \mathrm{Cu}_{30} \mathrm{P}_{20}$. It has been recently reported [11] that the quaternary addition of $\mathrm{Cu}$ increases the glassforming ability of the alloy.

\section{EXPERIMENTAL}

Amorphous alloys of compositions $\mathrm{Pd}_{46} \mathrm{Ni}_{36} \mathrm{P}_{18}, \mathrm{Pd}_{48} \mathrm{Ni}_{32} \mathrm{P}_{20}$ and $\mathrm{Pd}_{40} \mathrm{Ni}_{10} \mathrm{Cu}_{30} \mathrm{P}_{20}$ were prepared as both ribbon $(\approx 20 \mu \mathrm{m}$ thick) and wire $(\approx 100 \mu \mathrm{m}$ diameter) by single-roller melt spinning and rotating-water melt spinning, respectively. Bulk $\mathrm{Pd}_{40} \mathrm{Ni}_{10} \mathrm{Cu}_{30} \mathrm{P}_{20}$ was prepared by quenching in a water-cooled quartz tube. A Seiko Instruments SSC580DS was employed for DSC experiments, performed using $10 \mathrm{mg}$ samples in sealed $\mathrm{Al}$ crucibles, at a heating rate of $0.667 \mathrm{Ks}^{-1}$, under a dynamic flow of $\mathrm{Ar}\left(1.667 \mathrm{~m}^{3} \mathrm{~s}^{-1}\right)$ and using a standard $\mathrm{Al}_{2} \mathrm{O}_{3}$ reference.

Table 1: Interpolated glass transition temperatures $T_{8}$ and crystallization temperatures $T_{\text {cryst }}$ of amorphous $\mathrm{Pd}_{46} \mathrm{Ni}_{36} \mathrm{P}_{18}$, $\mathrm{Pd}_{48} \mathrm{Ni}_{32} \mathrm{P}_{20}$ and $\mathrm{Pd}_{40} \mathrm{Ni}_{10} \mathrm{Cu}_{30} \mathrm{P}_{20}$ in both ribbon and wire form, as measured by DSC at a heating rate of $0.667 \mathrm{Ks}^{-1}$.

\begin{tabular}{|c|c|c|c|c|c|c|}
\cline { 2 - 7 } \multicolumn{1}{c|}{} & \multicolumn{2}{c|}{$\mathrm{Pd}_{46} \mathrm{Ni}_{36} \mathrm{P}_{18}$} & \multicolumn{2}{c|}{$\mathrm{Pd}_{48} \mathrm{Ni}_{32} \mathrm{P}_{20}$} & \multicolumn{2}{c|}{$\mathrm{Pd}_{40} \mathrm{Ni}_{10} \mathrm{Cu}_{30} \mathrm{P}_{20}$} \\
\cline { 2 - 7 } \multicolumn{1}{c|}{} & ribbon & wire & ribbon & wire & ribbon & bulk \\
\hline$T_{g} / \mathrm{K}$ & 573 & 577 & 585 & 598 & 578 & 575 \\
$T_{\text {cryss }} / \mathrm{K}$ & 662 & 668 & 659 & 663 & 670 & 670 \\
\hline$T_{\text {crns }}-T_{8} / \mathrm{K}$ & 89 & 91 & 74 & 65 & 92 & 95 \\
\hline
\end{tabular}

Isothermal ageing in the supercooled liquid regions of the alloys (Table 1) was conducted in a saltbath or in a furnace for specimens sealed under a low pressure of argon in Pyrex. Heat-treatments were terminated by water quench. Specimens for APFIM analysis were prepared by standard single-stage eletropolishing ( $1 \%$ perchloric acid in butoxyethanol at $20 \mathrm{~V}$ d.c. at room temperature) of wire or blanks $(15 \times 0.02 \times 0.02 \mathrm{~mm})$ machined from the middle of the ribbon specimens, parallel to the spinning direction [12]. Specimens for TEM analysis were prepared by ion beam milling at $\approx 160 \mathrm{~K}$, employing an E.A. Fischione Instruments, Inc. Model 3000 Ion Mill.

The atom probe characterisations were performed using a reflectron-based time-of-flight atom probe, Applied Microscopy Ltd. APFIM 220 [13]. Field ion microscopy (FIM) was conducted between temperatures of 30 and $100 \mathrm{~K}$ in $\approx 15 \times 10^{-3} \mathrm{~Pa} \mathrm{Ne}$. Atom probe analysis was conducted between temperatures of 30 and $50 \mathrm{~K}$, employing a pulse fraction of 15 or $20 \%$ at a pulse repetition rate of $200 \mathrm{~Hz}$. In the atom probe mass spectra, the peak at $m / n=31.0$ was assigned to ${ }^{31} \mathrm{P}^{+}$since the natural isotopic abundance of ${ }^{62} \mathrm{Ni}^{2+}$ is small (3.59 at.\%). Note that preferential evaporation of $\mathrm{Cu}$ during analysis of the quartenary alloy resulted in compositions slightly lower than the nominal. Transmission electron microscopy characterisations were performed using a Philips CM 200 electron microscope operated at $200 \mathrm{kV}$ and a JEOL JEM-4000EX operated at $400 \mathrm{kV}$ was employed for high resolution electron microscopy (HREM). All compositions quoted are in at.\%.

\section{RESULTS}

\section{1 $\mathrm{Pd}_{46} \mathrm{Ni}_{36} \mathrm{P}_{18}$}

Figures 1(a) and 1(b) show Ne FIM images of as-quenched $\mathrm{Pd}_{46} \mathrm{Ni}_{36} \mathrm{P}_{18}$ and that annealed for $3600 \mathrm{~s}$ at $605 \mathrm{~K}$, respectively. The FIM image of the as-quenched microstructure is characterised by a random distribution of spots, typical of an amorphous alloy. Annealing for up to $3600 \mathrm{~s}$ at $605 \mathrm{~K}$ (within the supercooled liquid region) did not result in changes in the FIM image. Figure 2 shows corresponding composition depth profiles - annealing for up to $3600 \mathrm{~s}$ at $605 \mathrm{~K}$ did not show evidence of a compositionallymodulated microstructure. Table 2 summarises the results of statistical analysis. Figure 3 shows HREM 
micrographs and corresponding diffraction patterns of as-quenched material and that annealed for $3600 \mathrm{~s}$ at $605 \mathrm{~K}$. The microstructures of both are those of amorphous alloys: typical maze-pattern contrast is evident while the diffraction patterns show typical diffuse single halo patterns. Thus, there are neither chemical nor structural changes upon annealing for $3600 \mathrm{~s}$ at $605 \mathrm{~K}$, within the supercooled liquid region.

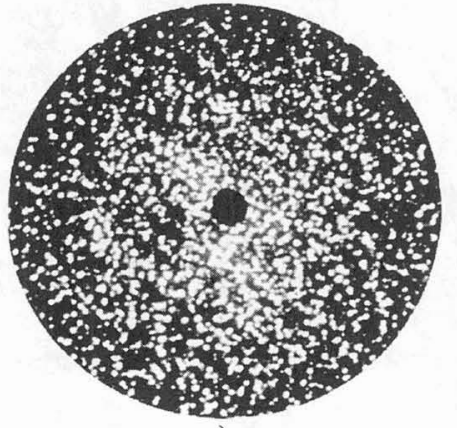

a)

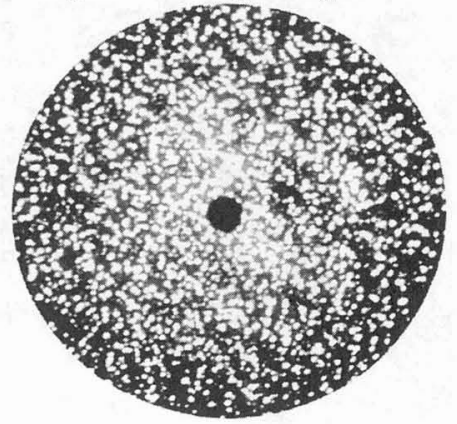

b)

Figure 1: FIM images of $\mathrm{Pd}_{46} \mathrm{Ni}_{36} \mathrm{P}_{18}$, observed at $30 \mathrm{~K}$ in Ne. (a) As-quenched and (b) annealed for $3600 \mathrm{~s}$ at $605 \mathrm{~K}$.

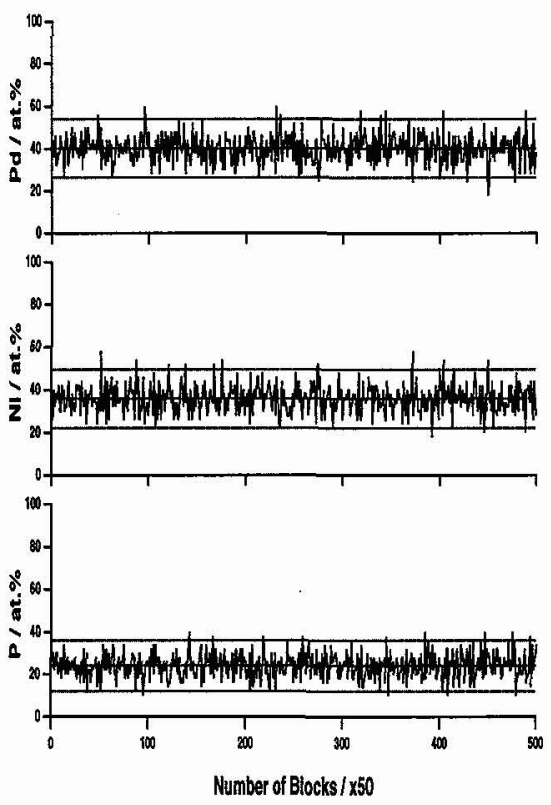

a)

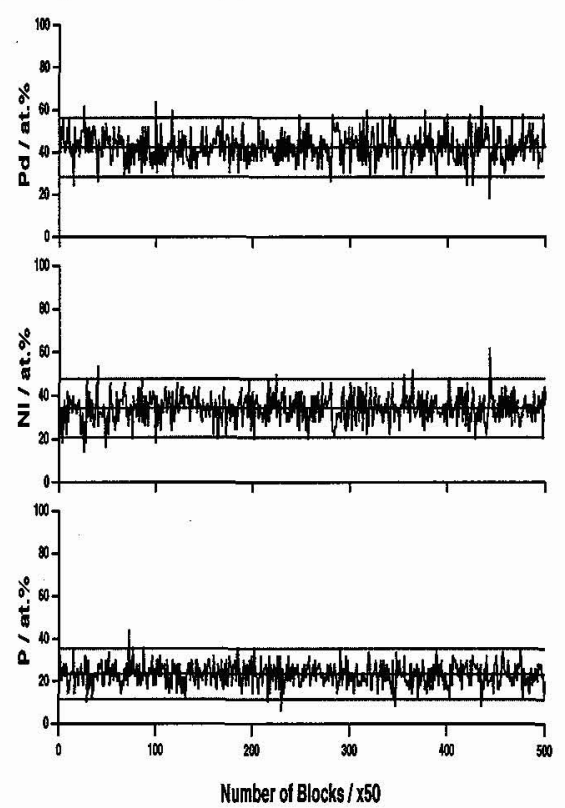

b)

Figure 2: Composition depth profiles for solute species in $\mathrm{Pd}_{46} \mathrm{Ni}_{36} \mathrm{P}_{18}$. Block size is 50 ions. Depth of analyses $\approx 100$ $\mathrm{nm}$. Horizontal dashed lines show the average solute contents and 95\% confidence intervals. (a) As-quenched and (b) annealed for $3600 \mathrm{~s}$ at $605 \mathrm{~K}$.

Table 2: Statistical analysis of composition frequency distributions, employing the $\chi^{2}$ test. d.f. is the degree of freedom.

\begin{tabular}{|c|c|c|c|c|c|c|c|c|}
\cline { 2 - 9 } \multicolumn{1}{c|}{} & \multicolumn{2}{c|}{$\mathrm{Pd}$} & \multicolumn{2}{c|}{$\mathrm{Ni}$} & \multicolumn{3}{c|}{$\mathrm{P}$} & \multicolumn{3}{c|}{$\mathrm{Cu}$} \\
\cline { 2 - 9 } \multicolumn{1}{c|}{} & $\chi^{2}$ & d.f. & $\chi^{2}$ & d.f. & $\chi^{2}$ & d.f. & $\chi^{2}$ & d.f. \\
\hline $\mathrm{Pd}_{46} \mathrm{Ni}_{36} \mathrm{P}_{18}$ (ASQ) & 8.03 & 16 & 13.1 & 16 & 3.8 & 14 & - & - \\
$\mathrm{Pd}_{46} \mathrm{Ni}_{36} \mathrm{P}_{18}$ (3600 s @ 605 K) & 16.6 & 18 & 18.7 & 17 & 28.2 & 15 & - & - \\
\hline $\mathrm{Pd}_{48} \mathrm{Ni}_{32} \mathrm{P}_{20}$ (ASQ) & 18.5 & 18 & 26.1 & 17 & 27.8 & 16 & - & - \\
$\mathrm{Pd}_{48} \mathrm{Ni}_{32} \mathrm{P}_{20}$ (300 s @ 613 K) & 29.4 & 17 & 27.0 & 16 & 18.5 & 15 & - & - \\
\hline $\mathrm{Pd}_{40} \mathrm{Ni}_{10} \mathrm{Cu}_{30} \mathrm{P}_{20}$ (ASQ) & 18.9 & 18 & 15.1 & 11 & 26.6 & 15 & 11.0 & 13 \\
$\mathrm{Pd}_{40} \mathrm{Ni}_{10} \mathrm{Cu}_{30} \mathrm{P}_{20}$ (600 s @ 600 K) & 14.6 & 18 & 11.9 & 11 & 16.6 & 16 & 9.1 & 15 \\
\hline
\end{tabular}




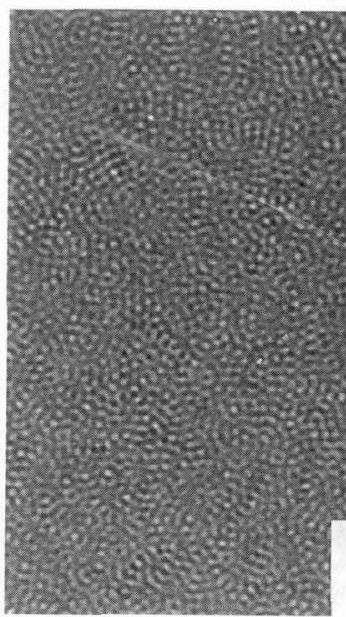

a)

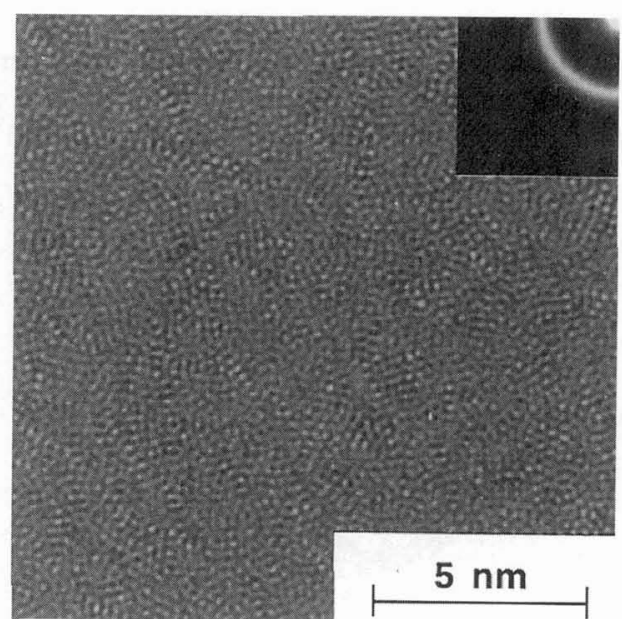

b)

Figure 3: HREM images and their corresponding selected area diffraction patterns (SADP) of (a) as-quenched $\mathrm{Pd}_{46} \mathrm{Ni}_{36} \mathrm{P}_{18}$; (b) $\mathrm{Pd}_{46} \mathrm{Ni}_{36} \mathrm{P}_{18}$ annealed for $3600 \mathrm{~s}$ at $605 \mathrm{~K}$.

\section{$3.2 \mathrm{Pd}_{48} \mathrm{Ni}_{32} \mathrm{P}_{20}$}

The FIM image of as-quenched $\mathrm{Pd}_{48} \mathrm{Ni}_{32} \mathrm{P}_{20}$ was characterised by a random distribution of spots, similar to those shown in Figure 1. Annealing for up to $300 \mathrm{~s}$ at $613 \mathrm{~K}$ did not result in changes in the FIM image. Figure 4 shows corresponding composition depth profiles - annealing for up to $300 \mathrm{~s}$ at $613 \mathrm{~K}$ did not show evidence of a compositionally modulated microstructure. Table 2 summarises the results of statistical analysis. Annealing for $900 \mathrm{~s}$ at $623 \mathrm{~K}$, however, resulted in primary crystallization of Pd-rich and Ni rich phases.

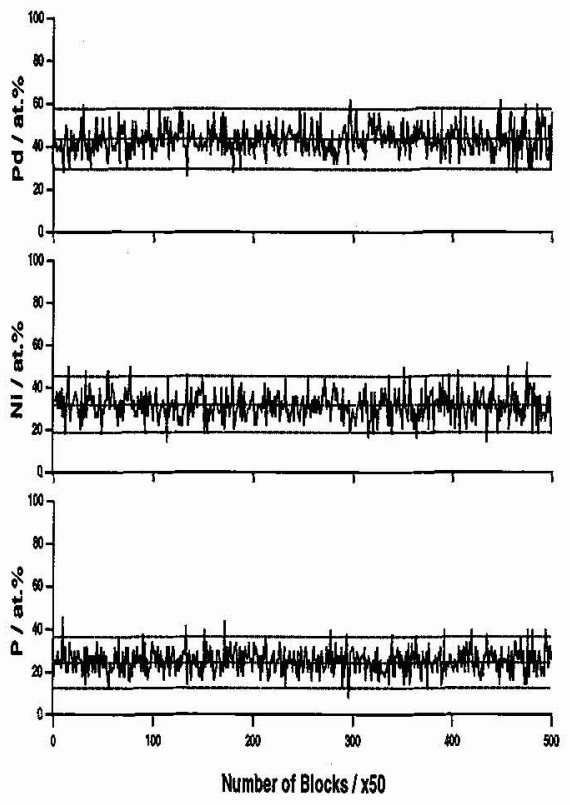

a)
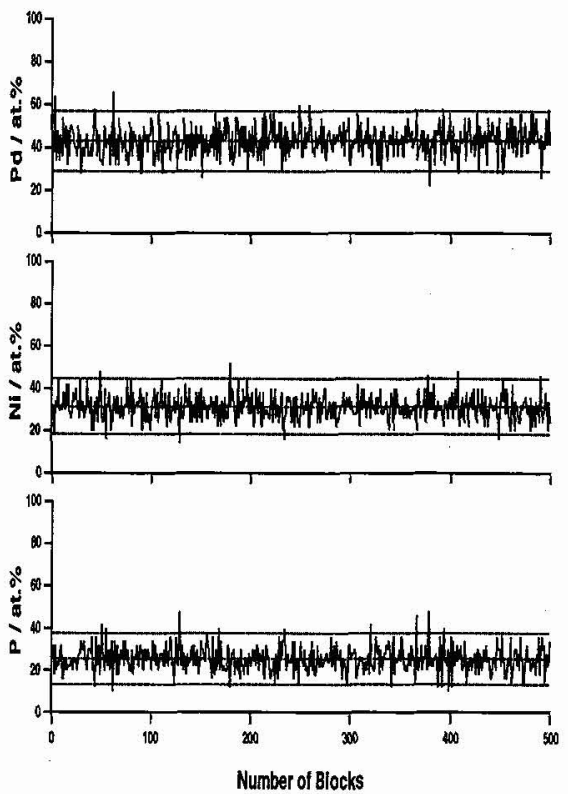

b) 


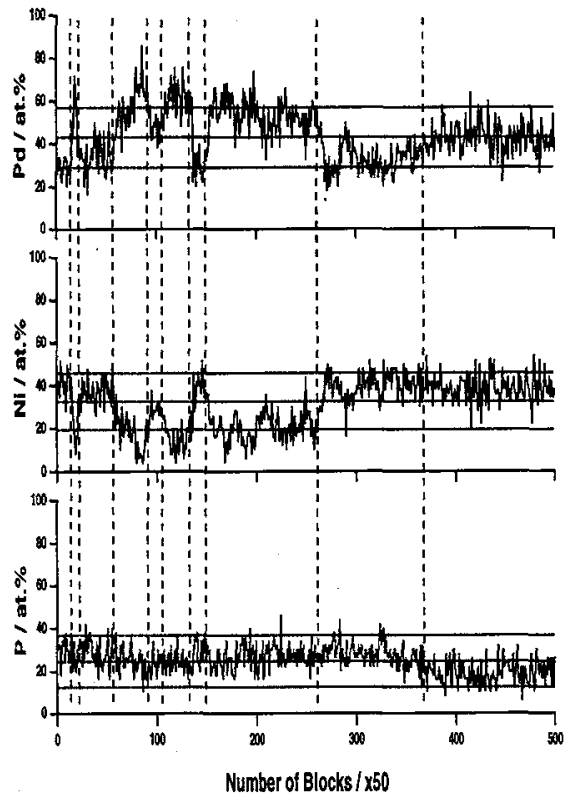

c)

\section{$3.3 \mathrm{Pd}_{40} \mathrm{Ni}_{10} \mathrm{Cu}_{30} \mathrm{P}_{20}$}

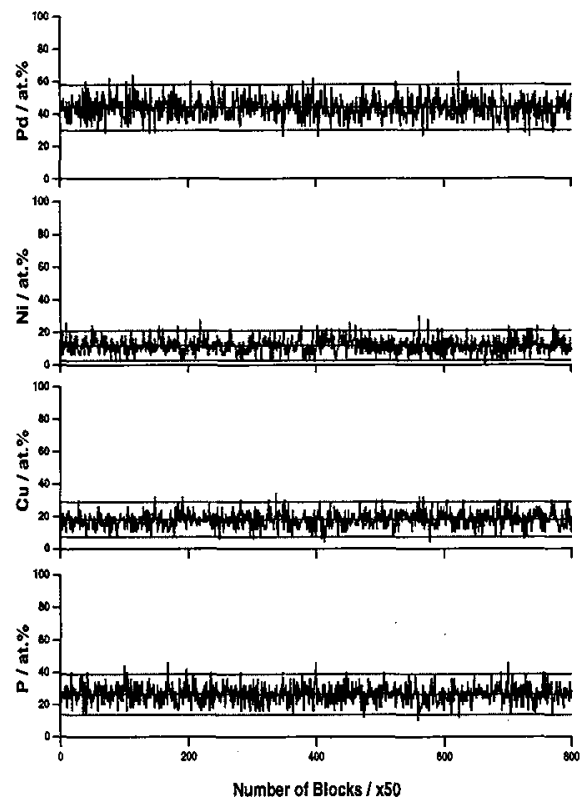

a)
Figure 4: Composition depth profiles for solute species in $\mathrm{Pd}_{48} \mathrm{Ni}_{32} \mathrm{P}_{20}$. Block size is 50 ions. Depth of analyses $\approx 100 \mathrm{~nm}$. Horizontal dashed lines show the average solute contents and $95 \%$ confidence intervals.

(a) As-quenched;

(b) annealed for $300 \mathrm{~s}$ at $613 \mathrm{~K}$;

(c) annealed for $900 \mathrm{~s}$ at $623 \mathrm{~K}$. Vertical dashed lines show some of the $\gamma$ /amorphous interfaces.

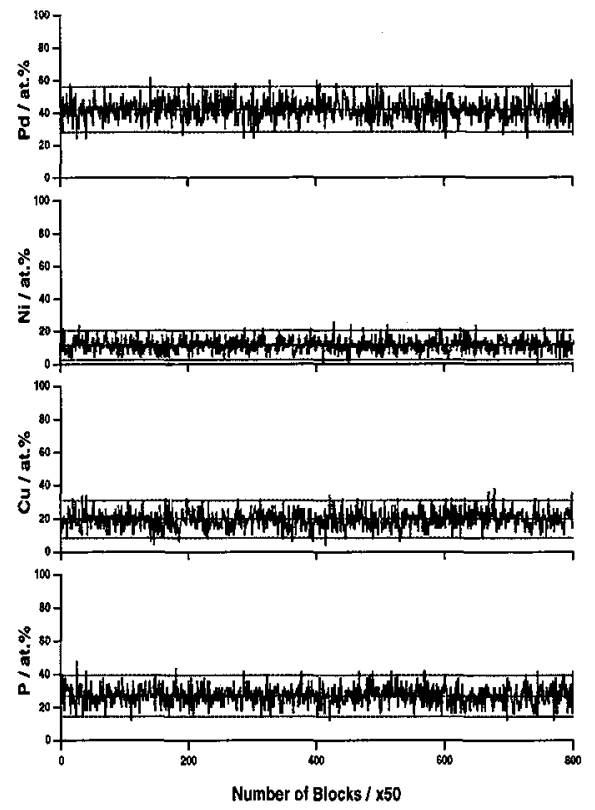

b)

Figure 5: Composition depth profiles for solute species in $\mathrm{Pd}_{40} \mathrm{Ni}_{10} \mathrm{Cu}_{30} \mathrm{P}_{20}$. Block size is 50 ions. Depth of analyses $\approx 160 \mathrm{~nm}$. Horizontal dashed lines show the average solute contents and $95 \%$ confidence intervals. (a) As-quenched $\mathrm{Pd}_{40} \mathrm{Ni}_{10} \mathrm{Cu}_{30} \mathrm{P}_{20}$ and (b) $\mathrm{Pd}_{40} \mathrm{Ni}_{10} \mathrm{Cu}_{30} \mathrm{P}_{20}$ annealed for $600 \mathrm{~s}$ at $600 \mathrm{~K}$. 
The FIM image of as-quenched $\mathrm{Pd}_{40} \mathrm{Ni}_{10} \mathrm{Cu}_{30} \mathrm{P}_{20}$ was characterised by a random distribution of spots, similar to those shown in Figure 1. Annealing for up to $600 \mathrm{~s}$ at $600 \mathrm{~K}$ (within the supercooled liquid region) did not result in changes in the FIM image. Figure 5 shows corresponding composition depth profiles - annealing for up to $600 \mathrm{~s}$ at $600 \mathrm{~K}$ did not show any evidence of a compositionally-modulated microstructure. Table 2 summarises the results of statistical analysis.

\section{DISCUSSION}

In the as-quenched state, $\mathrm{Pd}_{46} \mathrm{Ni}_{36} \mathrm{P}_{18}$ is characteristically amorphous: solute species are randomly distributed (within the limitations of the atom probe technique) in a non-crystalline structure. It has been previously claimed [5] that an amorphous alloy of the same composition phase separated within $60 \mathrm{~s}$ upon annealing in the temperature range 605 to $630 \mathrm{~K}$, forming Pd-rich and P-rich domains on a scale of $1 \mathrm{~nm}$, consistent with DSC experiments [1] and corroborated by APFIM [6]. However, this work clearly demonstrates that compositional fluctuations did not develop in $\mathrm{Pd}_{46} \mathrm{Ni}_{36} \mathrm{P}_{18}$ during annealing for up to $3600 \mathrm{~s}$ at $605 \mathrm{~K}$. Complementary HREM confirmed that the alloy remained single-phase amorphous. This is in agreement with the SAXS investigation of an alloy of the same composition [9]. Thus, in the absence of crystallization, no chemical fluctuations exist in $\mathrm{Pd}_{46} \mathrm{Ni}_{36} \mathrm{P}_{18}$, refuting the proposal of phase separation prior to crystallization. The lack of complementary structural information for previous APFIM analyses [6, 10] allows the suggestion that the observed compositional inhomogeneities were the result of partial crystallization, as seen in Figure 4(c). Initial crystallization results in the formation of nanocrystalline FCC Pd-rich, $\mathrm{P}$-poor solid solution $\left(\mathrm{Pd}_{40} \mathrm{Ni}_{59} \mathrm{P}_{1}\right)$ [7] and thus, $\mathrm{P}$ enrichment in the remaining amorphous fraction is expected. This is entirely consistent with the chemical hetrogeneities observed previously [6] which were attributed to phase separation, rather than crystallization. Future research will investigate the early stages of crystallization of $\mathrm{Pd}_{46} \mathrm{Ni}_{36} \mathrm{P}_{18}$.

Annealing of $\mathrm{Pd}_{48} \mathrm{Ni}_{32} \mathrm{P}_{20}$ in the supercooled liquid region did not result in the formation of composition fluctuations prior to crystallization. Note that the crystallization products may not be unambiguously identified at this stage but are the subject of continuing research. Similarly, no composition fluctuations were found in $\mathrm{Pd}_{40} \mathrm{Ni}_{10} \mathrm{Cu}_{30} \mathrm{P}_{20}$ upon annealing in the supercooled liquid region. Future research will investigate the early stages of crystallization of $\mathrm{Pd}_{40} \mathrm{Ni}_{10} \mathrm{Cu}_{30} \mathrm{P}_{20}$ to elucidate the mechanisms by which $\mathrm{Cu}$ improves the thermal stability of this family of amorphous alloys.

\section{CONCLUSIONS}

Neither compositional fluctuations nor structural transformations were detected by APFIM and HREM, respectively, upon annealing $\mathrm{Pd}_{46} \mathrm{Ni}_{36} \mathrm{P}_{18}$ for up to $3600 \mathrm{~s}$ within the supercooled liquid region. The experimental evidence negates the presence of a miscibility gap in this section of the PdNiP phase diagram. No compositional fluctuations were detected upon annealing $\mathrm{Pd}_{48} \mathrm{Ni}_{32} \mathrm{P}_{20}$ and $\mathrm{Pd}_{40} \mathrm{Ni}_{10} \mathrm{Cu}_{30} \mathrm{P}_{20}$ in the supercooled liquid region.

\section{REFERENCES}

[1] Chen H.S., Mater. Sci. Eng. 23 (1976) 151-154.

[2] Schluckeiber G. and Predel B., Z. Metallkunde 74 (1983) 569-576.

[3] Busch R., Schneider S., Peker A. and Johnson W.L., Appl. Phys. Letts. 67 (1995) 1544-1546.

[4] Jing J., Gonser U. and Wagner H.-G., Z. Metallkunde 78 (1987) 767-769.

[5] Yavari A.R., Hamar-Thibault S. and Sinning H.R., Scripta Metall. 22 (1988) 1231-1234.

[6] Oehring M. and Haasen P., J. Physique 47(C7) (1986) 275-280.

[7] Donovan P. E., Evans P.V. and Greer A.L., J. Mater. Sci. Letts. 5 (1986) 951-952.

[8] Boswell P.G., Scripta Metall. 11 (1977) 701-707.

[9] Yavari A.R., Osamura K., Okuda H. and Amemia Y., Phys. Rev. B 37 (1988) 7759-7765.

[10] Oehring M., Z. Metallkunde 80 (1988) 1-8.

[11] Inoue A., Nishiyama N. and Matsuda T., Mater. Trans JIM 37 (1996) 181-184.

[12] Hono K. and Sakurai T., Appl. Surf. Sci. $87 / 88$ (1995) 166-178.

[13] Waugh A.R., Richardson C.H. and Jenkins R., Surf. Sci. 266(1-3) (1992) 501-505. 